\title{
Plutonium Transport Package Closure Survey
}

by

S. W. Heaberlin

April 1978

Prepared for the

U.S. Department of Energy

under Contract EY-76-C-06-1830 


\title{
NOTICE
}

This report was prepared as an account of work sponsored by the United States Government. Neither the United States nor the Department of Energy, nor any of their employees, nor any of their contractors, subcontractors, or their employees, makes any warranty, express or implied, or assumes any legal liability or responsibility for the accuracy, completeness or usefulness of any information, apparatus, product or process disclosed, or represents that its use would not intringe privately owned rights.

The views, opinions and conclusions contained in this report are those of the contractor and do not necessarily represent those of the United States Government or the United States Department of Energy.

\author{
PACIFIC NORTHWEST LABORATORY \\ operated by \\ BATTELLE \\ for the \\ UNITED STATES DEPARTMENT OF ENERGY \\ Under Contract EY-76-C-06-1830
}

\author{
Printed in the United States of America \\ Avaitable from \\ National Technicil Information Service \\ United States Department of Cornmerce \\ 5785 Port Royal Road \\ Soringfieid, Virginia 22751
}

Price: Printed Cooys_: Microfiche $\$ 3.00$

NTIS

-Pages Selling Price

$001-025 \quad \$ 4.50$

$025-0.50+\$ 5.00$

$051-075 \quad 55.50$

$076-100 \quad \$ 6.00$

$701-125 \quad \$ 6.30$

$126-150 \quad 57.00$

$151-175 \quad \$ 7.75$

$176-200 \div \quad 58.50$

$201-225 \quad \cdot \quad \$ 8.75$

$225-250 \quad 59.00$

$251-275 \quad 510.00$

$276-300 \quad 510.25$ 
PLUTONIUM TRANSPORT PACKAGE

CLOSURE SURVEY

by

S. W. Heaberl in

Apri1 1978

BATTELLE

PACIFIC NORTHWEST LABORATORIES

RICHLAND, WASHINGTON 99352 


\section{ACKNOWLEDGMENT}

The author would like to acknowledge those PNL staff members who conducted the survey: L. C. Davenport, D. E. Friar, M. A. Lewallen, R. A. Libby and D. R. Oden. The author would also like to collectively thank all those who provided data for the survey. Their cooperation made this document possible. 
. 
BNWL-2288

\section{SUMMARY}

In the fall of 1976, Battelle, Pacific Northwest Laboratories conducted a survey of eight facilities receiving plutonium shipments to determine the condition of plutonium shipping packages during shipment. This survey followed a similar survey conducted by PNL in early 1974 .

The package types considered were the $L-10,6 M$ and $L L D-1$ packages. A total of 6,700 packages were included in the survey. Compared to the earlier survey, a marked reduction was observed in nonstandard package closure conditions. One exception was an increase in the occurrence of extremely tight pipe plugs in the $2 R$ inner container for the $6 \mathrm{M}$ package. This is not felt to be a significant safety problem.

The reduction in nonstandard package closure conditions was apparently due to the improved quality assurance in packing procedures. 
1 


\section{CONTENTS}

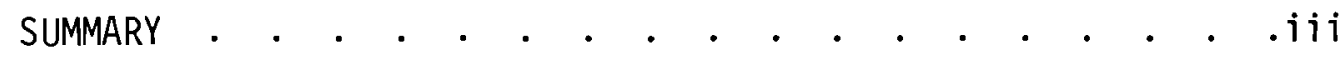

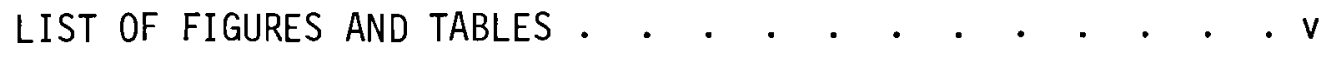

1.0 INTRODUCTION . • . . . . . . . . . . . . . 1

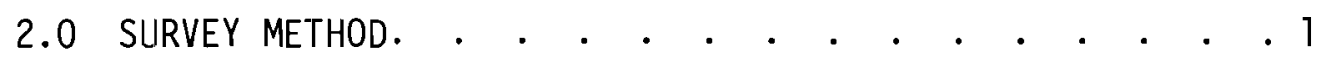

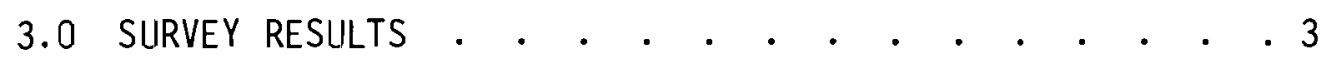

3.1 PARTICIPATING FACILITIES . . . . . . . . . . 3

3.2 SURVEY QUESTIONNAIRE SUMMARY . . . . . . . . . 4

3.3 INDUSTRY OBSERVATIONS ON PACKAGING AND

TRANSPORTATION. .. . . . . . . . . . . . . . . 8

3.4 CONCLUSIONS. . . . . . . . . . . . . . . . 9

APPENDIX A - 1976 SURVEY QUESTIONNAIRE

Survey Questions I - Receivers of $\mathrm{Pu}\left(\mathrm{NO}_{3}\right) 4$. . . . . . . A-1

Survey Questions II - Receivers of $\mathrm{Pu}_{2}$ 6M Packages . .A-4

Survey Questions III - Receivers of PuO 2 LLD-1 Packages. A-7

APPPENDIX B - DESCRIPTION OF PLUTONIUM TRANSPORT PACKAGES

B. 1 PLUTONIUM NITRATE PACKAGES L-10, L-3 . . . . . B-1

B.2 PLUTONIUM OXIDE PACKAGES - 6M, LLD-1 . . . . . . B-3 


\section{LIST OF FIGURES}

Figure B.1 L-10 Package . . . . . . . . . . B-2

Figure B.2 6M Package . . . . . . . . . . . B-4

Figure B.3 LLD-1 Package . . . . . . . . . . .

\section{LIST OF TABLES}

Table 3.1 Facilities Surveyed . . . . . . . . 3

Table 3.2 Estimated Number of Packages

Included in the Surveys. . . . . . . . 4

Table 3.3 Frequency of Observed Nonstandard

Package Closure Conditions . . . . . 5 


\subsection{INTRODUCTION}

In February of 1974, PNL surveyed nine receivers of plutonium. Information was obtained on the frequency of nonstandard package closure conditions for three common plutonium shipping packages, the L-10, 6M and LLD-1. (a) This survey covered the period from 1970 to early 1974. The results were presented in "Importance of Quality Control in Plutonium Packaging Loading" by C. L. Brown and S. W. Heaberlin at the 4th International Symposium on Packaging and Transportation of Radioactive Materials. The results were also used as the basis for Chapter 7 - Condition of Packages During Transport - of BNWL-1846, "An Assessment of the Risk of Transporting Plutonium Oxide and Liquid Plutonium Nitrate by Truck."

The information from this 1974 survey generated continued interest in the question of package closure errors. A second survey was authorized to determine the current state of packages in transport and to compare this with the results from the earlier survey. This report describes the second survey and gives its results.

\subsection{SURVEY METHOD}

The survey was conducted in four steps: 1) establish a facility contact, 2) provide a survey questionnaire, 3) visit the facility; and 4) prepare a site report. The first step was to estabiish a contact at the receiver facility. (b) The starting point was most often the individual or group contacted in the 1974 survey. In most cases staff and responsibilities had changed. Therefore new contacts were made. It was important that the facility contact be close to the operations staff (i.e., those handling the packages) while staying at a responsible management level. Where appropriate, the local Energy Research and Development Administration (ERDA) officials were also contacted to inform them of our activities. Often they became the main source of information.

a. The packages are described in Appendix $B$.

b. The facilities included in the survey are listed in Section 3.1 . 
After a contact was identified at the facility and agreed to participate in the survey, a questionnaire was sent. The questionnaire is shown in Appendix A. It is based on the form used in the 1974 survey with improvements and additions based on experience from the first survey.

A date to visit the facility was established during the initial contact. This date allowed the contact a reasonable amount of time to examine the questionnaire. During the visit, the questionnaire was discussed and questions were answered. If possible, the questionnaire was completed and given to the survey team. Additional information was also gained on events, experiences, opinions and suggestions covering a variety of transportation related i tems.

After the facility visit the survey team summarized the information acquired in a site report which was then given to the original facility contact for comment. This follow up was eigher by phone or letter.

These steps were generally followed but deviations from the procedure did occur. For example, in one instance, the facility was not visited. The site interview was conducted entirely by phone.

Two important elements were incorporated into the survey method. First, each facility was surveyed as a receiver of plutonium packages because package closure problems are most readily observable at the time of unpacking. This also allows observation of package integrity problems which may originate during transport. Reports of closure problems were therefore, a reporting of someone else's problem rather than their own. Second, to assure the anonymity of the individual site report, the results are for all sites collectively. 


\subsection{SURVEY RESULTS}

The results of the survey are described in this section. The results from the 1974 survey, which covered the period from 1970 to early 1974, will be compared to that of the 1976 survey, which covered the period from early 1974 to the fall of 1976 .

\subsection{PARTICIPATING FACILITIES}

The 1974 survey was conducted at nine facilities. Between 1974 and 1976 two of these facilities terminated their plutonium activities. One site not surveyed in 1974 was added in the 1976 survey. The facilities included in the two surveys are listed in Table 3.1 .

\section{TABLE 3.1 Facilities Surveyed}

\section{Survey}

Argonne National Laboratory

Argonne, Il 7 ino is

E. I. duPont deivemours

Savannah River Plant

Aiken, South Carolina

Union Carbide Corporation

Oak Ridge National Laboratory

Oak Ridge, Tennessee

Los Alamos Scientific Laboratory

Los Alamos, New Mexico

NUMEC

Babcock and Wilcox Company

Apol 1o, Pennsylvania

Atlantic Richfield Hanford Company

Richland, Washington

Rocky Flats Plant

The Dow Chemical Company

Golden, Colorado

New York State Atomic and

Space Development Authority

New York, New York

Kerr-McGee Nuclear Corporation

Oklahoma City, Oklahoma

\section{Survey}

Argonne National Laboratory

Argonne, Illinois

E. I. duPont delvemours

Savannah River Plant

Aiken, South Carui ina

Union Carbide Corporation

Oak Ridge National Laboratory

Oak Ridge, Tennessee

Los Alamos Scientific Laboratory

Los Alamos, New Mexico

NUMEC

Babcock and Wilcox Company

Apollo, Pennsylvania

Atlantic Richfield Hanford Company

Richland, Washington

Rocky Flats Plant

The Dow Chemical Company

Golden, Colorado

Mound Laboratory

Monsanto Research Corporation

Miamisburg, Ohio 


\subsection{SURVEY QUESTIONNAIRE SUMMARY}

Each of the eight facilities contacted in 1976 filled out a survey questionnaire. The questionnnaire used is shown in Appendix A. The facilities surveyed in 1974 filled out a similar form. The results obtained from these forms are summarized in Tables 3.2 and 3.3. Table 3.2 gives the total number of received packages covered in the survey by package type for the two periods. Table 3.3 summarizes the frequency of nonstandard package closure conditions observed. The frequency is given in observations per package shipped.

\section{TABLE 3.2 Estimated Number of Packages}

Included in the Surveys

Package (a)

$\mathrm{L}-10, \mathrm{~L}-3$

$6 \mathrm{M}$

LLD-1

$\begin{array}{ll}\frac{1974 \text { Survey }^{(b)}}{2130^{(d)}} & \frac{1976 \text { Survey }^{(c)}}{219^{(f)}} \\ 1243 & \sim 3080^{(g)} \\ 2700-3000^{(e)} & \sim 3400^{(g)}\end{array}$
a. The packages are described in Appendix B.
b. Period of 1970 to early 1974.
c. Period of early 1974 to fall 1976.
d. Includes some ${ }^{233} U$ shipped in the same manner as liquid plutonium nitrate.
e. Includes some plutonium metal shipments.
f. Eight were L-3's, all others L-10's.
g. Includes some ${ }^{233} \mathrm{UO}_{2} / \mathrm{ThO}_{2}$ shipments. 
TABLE 3.3 Frequency of Observed Nonstandard

Package Closure Conditions

\begin{tabular}{cc} 
& Estimated \\
& Observation \\
& Frequency \\
Observation & (per container received) \\
\hline
\end{tabular}

Part I - L-3 and L-10 Packages

Outside Primary Containment Vessel

1. Bolt ring on outer drum turned upward

$2.2 \times 10^{-2}$

0.0

2. Vermiculite level low

$9.4 \times 10^{-2}$

3. Vermiculite contaminated

$1.9 \times 10^{-3}$

0.0

$5.0 \times 10^{-4}$

0.0

4. Vermiculite waterlogged

$6.1 \times 10^{-3}$

0.0

5. No cap on vent line

$1.4 \times 10^{-3}$

0.0

6. Vent cap loose

$7.5 \times 10^{-3}$

0.0

7. Valve on vent line not closed

$2.4 \times 10^{-2}$

0.0

8. Flange bolts too tight (over 80-ft $1 \mathrm{~b}$ torque)

$9.4 \times 10^{-4}$

0.0

9. Gasket missing

10. Improper gasket material

NA $(b)$

0.0

$7.8 \times 10^{-2}$

Inside Primary Containment Vessel

1. Plastic bag pressurized

$2.4 \times 10^{-3}$

0.0

2. Plastic bottle cap loose

3. Plutonium solution in plastic bag

$4.7 \times 10^{-4}$

0.0

$7.0 \times 10^{-2}$

0.0

4. Contamination outside plastic lag

$1.2 \times 10^{-2}$

0.0

5. Plutonium solution outside

$5.2 \times 10^{-3}$

0.0 plastic bag

6. Plastic bottle gasket in "figure eight"

$1.9 \times 10^{-3}$

0.0

7. Plastic bag broken

$9.4 \times 10^{-4}$

0.0

8. Low acid molarity

$\mathrm{NA}$ (b)

$7.8 \times 10^{-2}$

a. The 1976 survey included only 219 L-10/L-3 type packages. Frequencies of $5 \times 10^{-3}$ or less would not appear. For this reason, direct comparison between the 1974 and 1976 surveys may not be valid.

b. Not Applicable, this item was not included in the 1974 survey. 
TABLE 3.3 (Continued)

$\begin{array}{ccc} & \text { TABLE 3.3 (Continued) } & \begin{array}{c}\text { Estimated } \\ \text { Observation } \\ \text { Frequency }\end{array} \\ \text { Obervation } & \text { (per container received) } \\ \text { 1974 Survey } & 1976 \text { Survey }\end{array}$

Part II - Plutonium 0xide Shipments in 6M Packages

Outside Primary Containment Vessel

1. Hole in outer drum

2. Bolt rings turned upward

$1.6 \times 10^{-3}$

0.0

3. Bolt ring bolt loose (finger tight)

$5.3 \times 10^{-2}$

0.0

4. Bolt ring bolt broke off while

$1.2 \times 10^{-1}$

0.0 tightening

$2.0 \times 10^{-2}$

0.0

5. Tamper indication seal broken

6. Plug in $2 R$ containment vesse 1 not tight
$\mathrm{NA}(\mathrm{aj})$
$2.2 \times 10^{-1}$
$1.6 \times 10^{-3}(b)$
0.0
0.0
$3.2 \times 10^{-4}$
0.0
$5.7 \times 10^{-2(c)}$

7. Threads damaged

8. Plug extremely tight

Inside Primary Containment Vessel

1. Can bulged due to internal pressure $5 \times 10^{-4}$

0.0

0.0

2. Contamination outside of can

0.0

$3.2 \times 10^{-4}$

3. Contamination of plastic bag

0.0

Part III - Plutonium 0xide Shipments in LLD-I Packages

Outside Primary Containment Vessel

1. Locking cover loose

2. Tamper indication seal broken
$4 \times 10^{-4}$
$N A^{(a)}$
$2.9 \times 10^{-3}$
0.18
0.0
0.0

3. Plug in $2 R$ containment vessel not tight

4. Threads damaged

$2.4 \times 10^{-4}$

5. Plug extremely tight

$2.4 \times 10^{-4}$

6. 0 ring missing

$3.9 \times 10^{-3}$

$6.2 \times 10^{-3}(d)$

$2.6 \times 10^{-3}$

a. NA - Not asked in this survey.

D. Not all packages have tamper seals.

c. Approximately $6 \%$ of the se are pipe caps, others are pipe plugs, also $93 \%$ of these occurrences were reported by a single receiver.

d. Approximately $10 \%$ of these are flanged $2 \mathrm{R}$ containers. 
TABLE 3.3 (Continued)

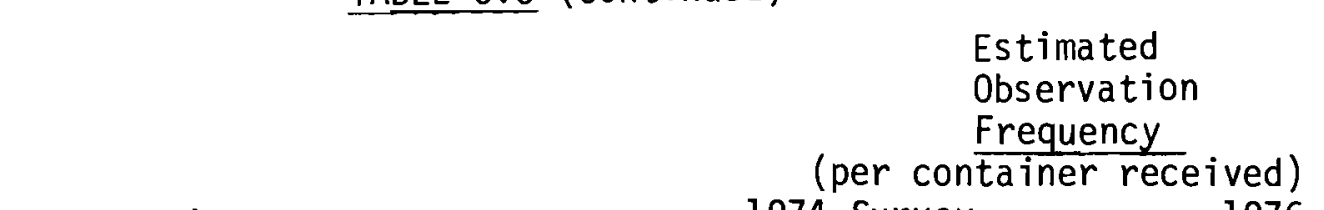

Observation 1974 Survey

1976 Survey

Inside Primary Containment Vessel

1. Can bulged due to internal pressure

2. Can breached or not completely sealed upon arrival

3. Contamination outside can but not outside containment vessel

$4.9 \times 10^{-4}$

$1.1 \times 10^{-3}$

$1.1 \times 10^{-3}$ 


\subsection{INDUSTRY OBSERVATIONS ON PACKAGING AND TRANSPORTATION}

During the facility visit, much additional information was gained in conversations with the facility staff. This information consisted of opinions, theories, suggestions and general comments. Although the validity of the statements was not researched, they are 1 isted here to indicate the current thinking of some members of the industry. The following list summarizes the most significant of these.

1. More stringent $Q A$ in package closure procedures were introduced in the period 1972-1974.

2. Most facilities felt their own closure procedures had improved somewhat but packages received had improved significantly.

3. Documentation, records control and training had improved.

4. Concern was expressed on the ban of nitrate shipments. It was felt that nitrate spills would be easier to contain than oxide spills. Use of the foam glass package in place of the vermiculite insulation of the $L-10$ would reduce or remove the present safety disadvantage of the nitrate form.

5. The first PNL survey report suggested the use of luting material such as teflon tape on $2 \mathrm{R}$ threads. In cases where teflon tape was used on machined threads, rather than pipe thread, binding and excessive tightness resulted. It should be noted that not all of the extremely tight plugs 1 isted in Table 3.3 suffered this fate.

6. Some incidence of the over zealous use of fluid luting/lubricant was reported. This resulted in the product cans being smeared with lubricant.

7. Criticism of the 12-31-74 amendment to the $6 \mathrm{M}$ certificate were made. Some of the new requirements were felt to be excessive and not to contribute to safety. In particular the venting requirement was thought to possibly weaken the containment.

8. Better documentation to accompany the packages was suggested. In some cases, especially scrap, contents are ill defined. Also the nature of the package might be better defined, for instance, the addition of an exploded parts figure.

9. Training for drivers and transport handlers could be improved. Instances of sloppy handling indicate a lack of understanding of the package arid material being transported.

10. A few instances of careless handling of empty packages were al so reported. Loss of control of the package and severe damage both were noted. 


\subsection{CONCLUSIONS}

The conclusions from this survey are determined by comparing the 1974 survey and the 1976 survey. The conclusions are drawn from both the questionnaire data and industry observations.

- Although both surveys indicated some level of package integrity insult, there were no reported instances of complete package containment failure or leakage of any plutonium for either period.

- The frequency of package closure problems for the period 1974 to 1976 is significantly less than that for 1970 to 1974 .

- The quality assurance for package closure procedures increased at the same time as improvements in package conditions. The better quality assurance is most likely responsible for that improvement.

- While the total number of packages included in both surveys was nearly equal, there was a marked reduction in the use of $L-10, L-3$ nitrate solution shipments. The majority of the difference seemed to be taken up by an increased use of the $6 \mathrm{M}$ package.

*The greatest exception is the increase in frequency of extremely tight $2 \mathrm{R}$ plugs. While there was an increase for LLD-1 packages the most dramatic increase was in the $6 \mathrm{M}$ packages. The $2 \mathrm{R}$ container used in the $6 \mathrm{M}$ generally does not contain an 0-ring seal, using rather a tapered plug to provide leak tightness. Therefore an overtight plug, while an inconvenience to the receiver, does not significantly affect the integrity of the package during shipment. 2R containers using 0-ring seals, such as those used in LLD-1 packages, are affected by over tightening. This would result in an over compressed 0-ring and possibly a bad seal. 
APPENDIX A

1976 SURVEY QUESTIONNAIRE 


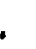


Survey Questions I - Receivers of $\mathrm{Pu}\left(\mathrm{NO}_{3}\right)_{4}$

A. Shipments

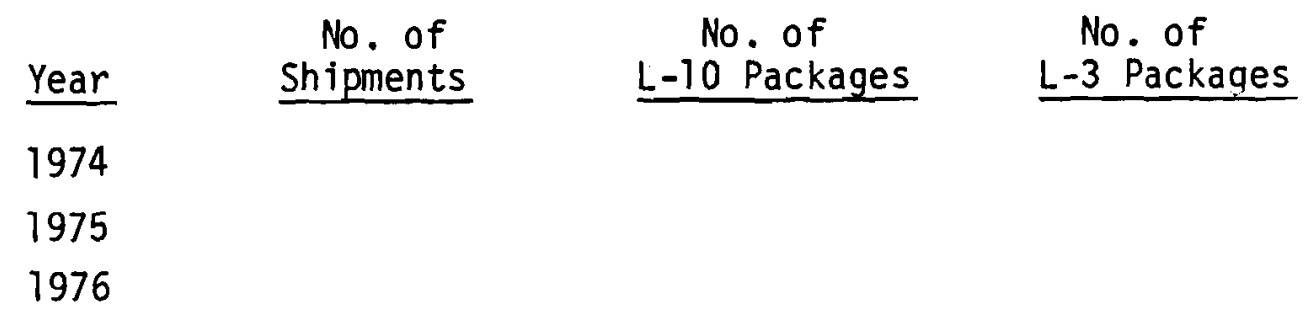

B. Outside Primary Containment Vesse]

Occurrence

1. Visible external damage

2. Puncture in outer drum

3. Packages having tamper indication seal

4. Tamper indication seals broken

5. Bolt ring on outer drum turned upward

6. Packages using vermiculite as packing/ insulating material

7. Low vermiculite level

8. Inner vessel exposed by low vermiculite level

9. Vermiculite contaminated

10. Vermiculite waterlogged

11. No cap on vent line

12. Vent cap loose

13. Valve on vent line not closed

14. Flange bolts loose or missing

15. Flange bolts too tight (over $80 \mathrm{ft}$. $1 \mathrm{~b}$ torque)

16. Flange gasket missing 
C. Inside Primary Containment Vessel

\section{Occurrence}

No. of

Occurrences

1. Plastic bag pressurized

2. Contamination outside plastic bag

3. Plutonium solution outside plastic bag

4. Plastic bag broken

5. Plutonium solution in plastic bag

6. Plastic bottle cap loose

7. Plastic bottle gasket in "figure eight"

8. Plastic bottle ruptured

D. Reusabilitv of Packages

\section{Occurrence}

1. Outer drum not reusable

(reason for rejection)

2. Outer drum reusable after repair (specify-weld, paint, etc.)

3. Inner steel vessel not reusable (reason for rejection) 
Dccurrences

4. Inner steel vessel reusable after repair (specify-weld, new flange bolts, venting repair, etc.)

5. Plastic bottle reused (specify repaired need for reuse-cleaning, seam sealing, new cap, etc.) 


\section{Survey Questions II - Receivers of $\mathrm{PuO}_{2}$ 6M Packages}

A. Shipments

\begin{tabular}{|c|c|c|}
\hline Year & $\begin{array}{c}\text { No. of } \\
\text { Shipments }\end{array}$ & $\begin{array}{c}\text { No. of } \\
\text { Packages }\end{array}$ \\
\hline 1974 & & \\
\hline 1975 & & \\
\hline 1976 & & \\
\hline
\end{tabular}

B. Outside Primary Containment Vessel

\section{Occurrence}

No. of

Occurrences

1. Visable external damage

2. Puncture in outer drum

3. Packages with tamper indication seal

4. Tamper indication seals broken

5. Bolt ring on outer drum turned upward

6. Bolt ring bolt loose (finger tight)

7. Bolt ring bolt broke off while tightening

8. Insulatina disks missing

9. Contamination outside of $2 R$ containment vesset

10. Plug in $2 R$ containment vessel not tigint

11. 2R plug extremeiy tight

C. Inside Primary Containment Vessel

\section{Occurrence}

1. $2 R^{\prime} s$ designed for 0 -ring

2. For $2 R^{\prime} s$ normally having 0 -ring, 0 -ring missing
No. of Occurrences 
3. For $2 R^{\prime}$ 's normally without 0 -ring, no luting (sealant) on threads

4. Threads on plug or $2 R$ pipe damaged

5. Can breached or not completely sealed

6. Contamination outside of can

7. Can bulged due to internal pressure

8. Contamination outside plastic bag

D. Reusability of Packages

\section{Occurrence}

1. Outer drum not reusable (reason for rejection)

2. Outer drum reusable after repair (specify-weld, paint, etc.) 
3. $2 R$ container not reusable (reason for rejection)

4. $2 R$ container reusable after repair (specify-weld, rethread, etc.) 
Survey Questions III - Receivers of Pu0 2 LLD-1 Packages

A. Shipments

\begin{tabular}{lll} 
Year & $\begin{array}{c}\text { No. of } \\
\text { Shipments }\end{array}$ & $\begin{array}{l}\text { No. of } \\
\text { Packages }\end{array}$ \\
\hline 1974 & & \\
1975 & & \\
1976 & &
\end{tabular}

B. Outside Primary Containment Vessel

Occurrence

No. of

Occurrences

1. Visable external damage

2. Locking cover Toose

3. Packages with tamper indication seals

4. Tamper indication seals broken

5. Padding material missing

6. Contamination outside of $2 \mathrm{R}$ containment vesse 1

7. Plug in $2 R$ containment vessel not tight

8. $2 R$ plug extremely tight

C. Inside Primary Containment VesseI

Occurrence

No. of

Occurrences

1. $2 R^{\prime} s$ designed for $0-r i n g$

2. For $2 R$ 's normally having 0-ring, 0 -ring missing

3. For $2 R^{\prime}$ 's normally wi thout 0-ring, no luting (sealant) on threads

4. Threads on plug or $2 R$ pipe damaged 
5. Can breached or not completely sealed

6. Contamination outside of can

7. Can bulged due to internal pressure

8. Contamination outside plastic bag

D. Reusability of Package

Occurrence

No. of

Occurrences

1. Outer package not reusable

(reason for rejection)

2. Outer package reusable after repair (specify - straighten birdcage, weld outer vessel, paint, etc.) 
3

Occurrence

No. of

Occurrences

3. $2 R$ container not reusable

(reason for rejection)

4. $2 R$ container reusable after repair (specify -weld, rethread, etc.) 


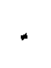

. 


\section{APPENDIX B}

DESCRIPTION OF PLUTONIUM TRANSPORT PACKAGES 


\section{APPENDIX B}

\section{PACKAGE DESCRIPTION}

Three plutonium transport packages were covered in this survey. Two packages, the 6M and LLD-1, are used primarily in the transport of solid plutonium compounds. The third package, the $L-10$, is used to ship liquid plutonium usually in the form of plutonium nitrate. Some data was also obtained for the L-3 package. The package is very similar to the $L-10$ but reduced in capacity. The $L-10$ data presented is the combination of L-10 and L-3 data collected. Each of the packages is described below.

\section{B. 1 PLUTONIUM NITRATE PACKAGES L-10, L-3}

The form of the plutonium product is plutonium nitrate $\left[\mathrm{Pu}\left(\mathrm{NO}_{3}\right)_{4}\right]$ in 3 - 6 molar nitric acid. Plutonium nitrate solution is normally shipped at a concentration of about $250 \mathrm{~g} \mathrm{Pu} / 1$ iter. The most commonly used containers for $\mathrm{Pu}\left(\mathrm{NO}_{3}\right)_{4}$ are the $\mathrm{L}-3$ and $\mathrm{L}-10$. These hold 31 iters and 101 iters of solution, respectively. The outer container of the $L-3$ container is a $208 \ell$ (55 gallon) drum and the outer container of the L-10 is two $208 \&$ drums welded end-to-end.

A single shipment is limited by criticality safety considerations to 68 bottles, or a total of $170 \mathrm{~kg}$ of plutonium. A diagram of the L-10 container is shown in Figure B.1. Details taken from the "Directory of Packagings for Transportation of Radioactive Materials" WASH 1279, USAEC, 1973 are summarized below:

\section{Authorized Contents}

Up to 10.5 liters per package UHN solutions having concentration of $235_{U}$ not exceeding $350 \mathrm{~g} / 1$ iter, or having a combined concentration of ${ }^{233} \mathrm{U}$ and ${ }^{235} \mathrm{U}$ not exceeding $250 \mathrm{~g} / 1 \mathrm{iter}$; or plutonium nitrate solutions of concentration not exceeding $250 \mathrm{~g}{ }^{239} \mathrm{Pu} / 1$ iter; or $4.5 \mathrm{~kg}$ dry $\mathrm{Pu}-\mathrm{U}$ compounds and mixtures.

Interior and Exterior Dimensions

Pressure vessel - $12.2 \mathrm{~cm}$ ID $\times 132.6 \mathrm{~cm}$ deep inside; Drum - $61 \mathrm{~cm}$ diam. $\times 169 \mathrm{~cm}$ in. high outside $\times 18 \mathrm{ga}$. wall. 


\section{L-10 CONTAINER}
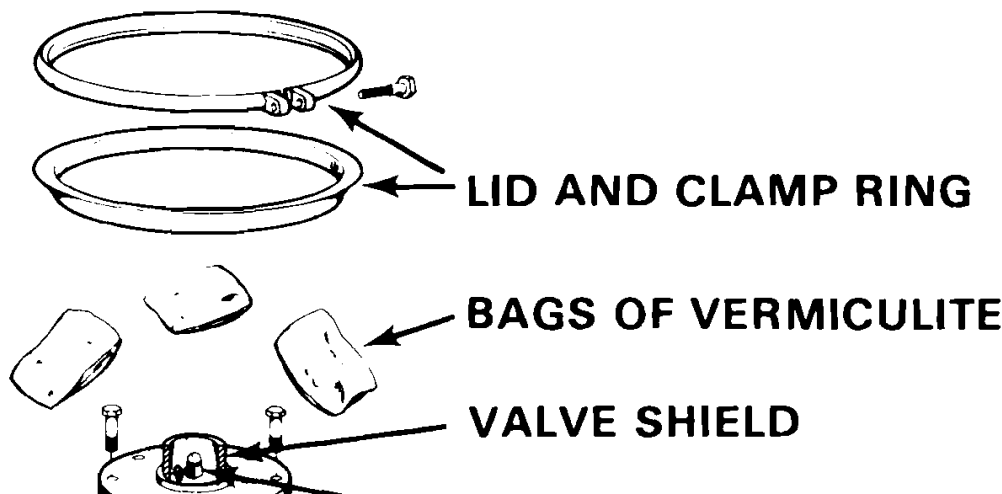

VENT VALVE

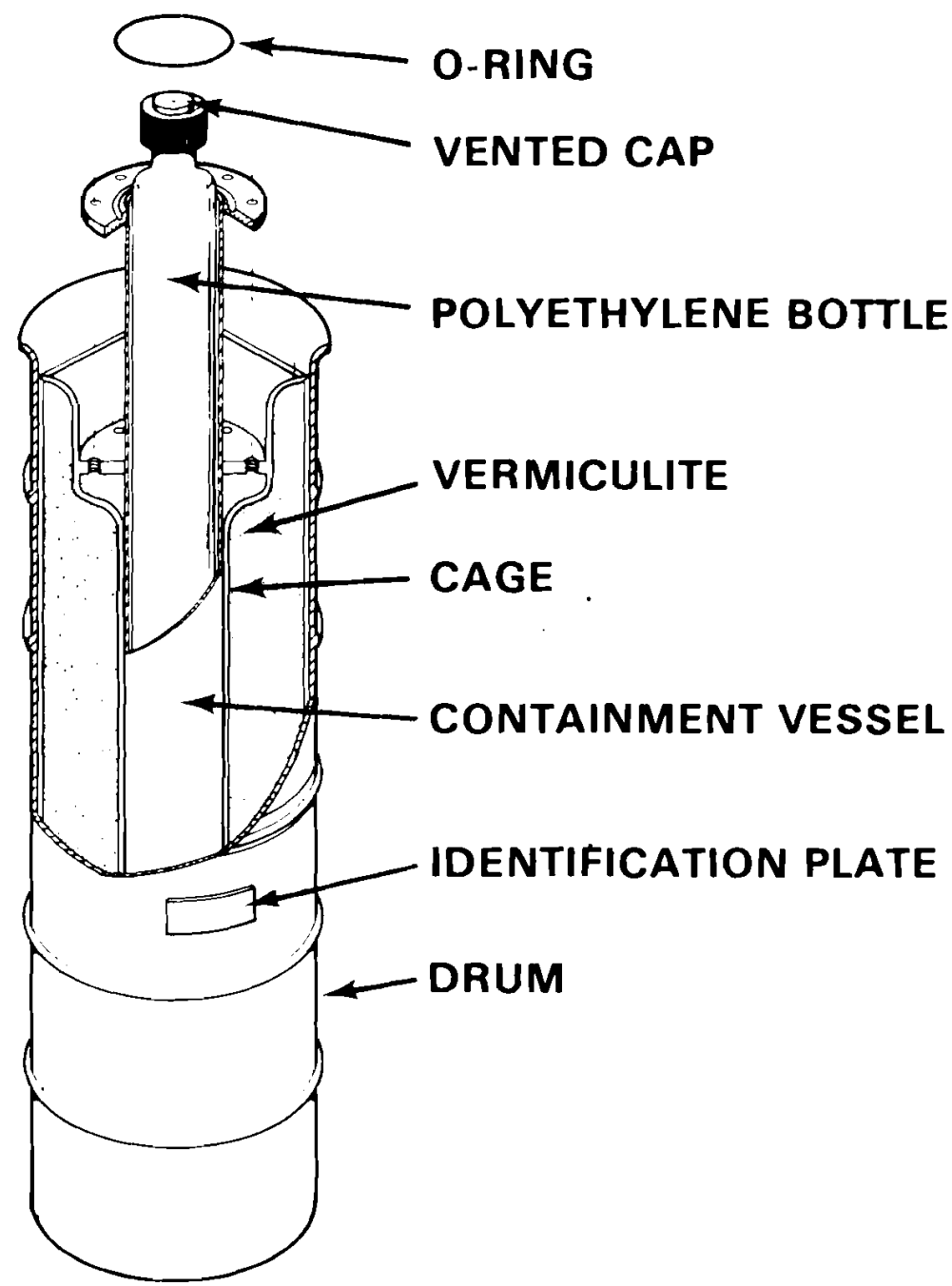

FIGURE B. 1 L-10 Package 
Description of Container

Outer container consists of two 208 \& DOT Spec. $17 \mathrm{H}$ drums end-to-end. Inner container is a stainless steel pressure vessel (200 Atm at $300^{\circ} \mathrm{C}$ ) supported inside the drum by a tubular steel frame. Annular space is filled with vermiculite for thermal insulation. The product solution is contained in a 10-1iter polyethylene bottle sealed in a polyvinylchloride bag and then inserted into the pressure vessel, with a thin neoprene pad to cushion the bottom of the bottle. Weight: $231 \mathrm{~kg}$, total; $206 \mathrm{~kg}$ without bottle. Type and Thickness of Shielding

$23 \mathrm{~cm}$ vermiculite insulation.

Heat Removal Capacity

Not applicable.

Authorized Modes of Transport

Cargo-only aircraft, motor vehicle, rail and vessel. May be used for fissile Class II or Class III.

\section{B.2 PLUTONIUM OXIDE PACKAGES - 6M, LLD-1}

Two 1 icensed plutonium oxide containers are described here. These are the $61-1$ and LLD-1 containers. Both of these packages can be used to transport a variety of fissile compounds in addition to plutonium oxide.

DOT Specification 6M Containers

The $6 \mathrm{M}$ designation represents a class of containers which have been approved for radioactive material transport. The general set of design criteria are found in 49CFR 178.104. The outer drum must conform to Spec. 6C and 17C as defined under paragraph 178.99 and 178.115, respectively. The inner container design must meet or exceed the $2 \mathrm{R}$ specification presented in paragraph 178.34 .

The outer container of the 6M can vary from a 38 to 416 liter capacity. The following description is based on the 57 liter size. This size 6M was used throughout the report and is shown in Figure B.2. Much of the information shown below was taken from WASH-1279. Other information has been obtained from actual container measurements. 


\section{M CONTAINER}

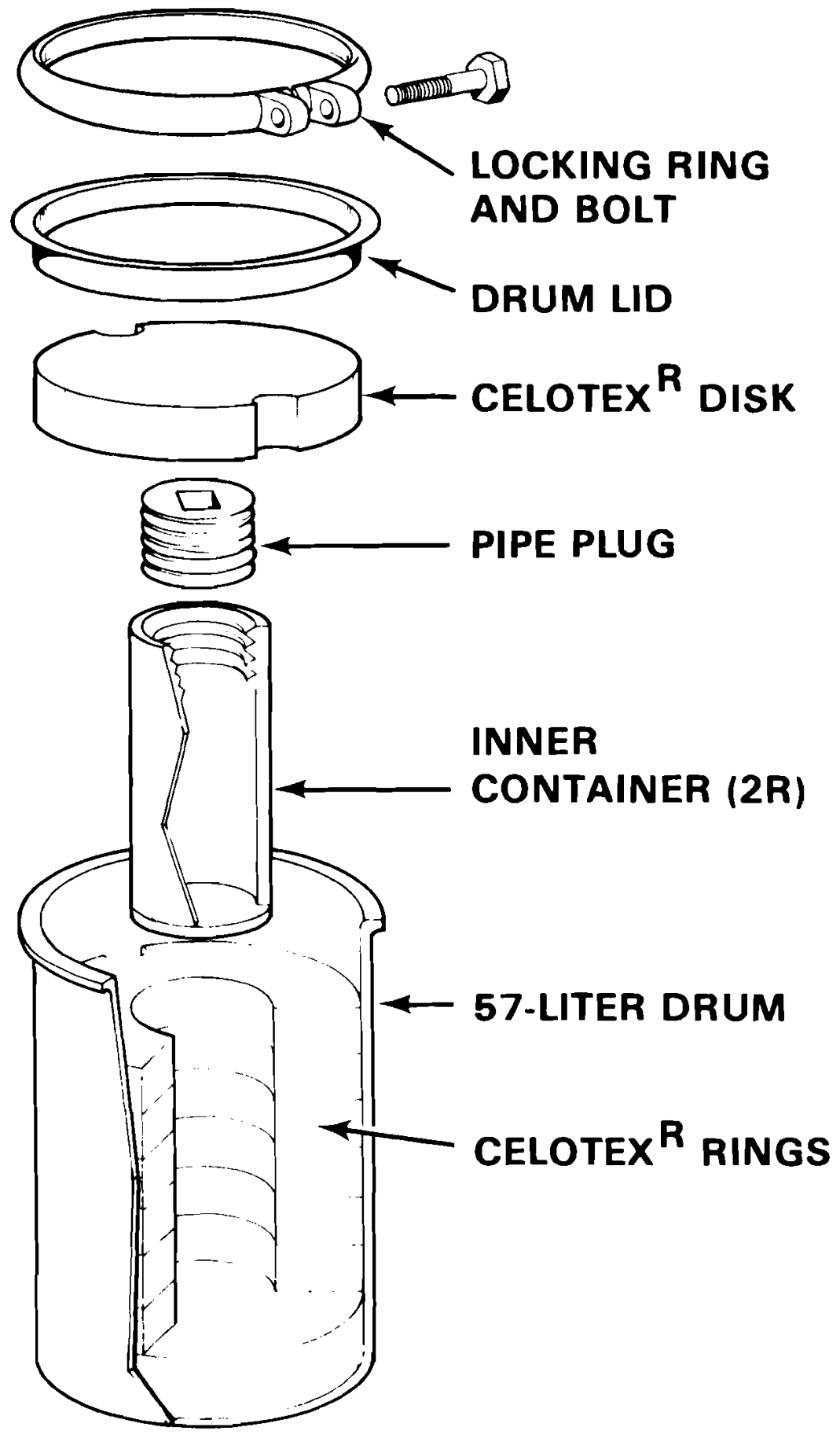

FIGUIRE B.2 6M Package (57-Liter) 


\section{Authorized Contents}

Up to $4.5 \mathrm{~kg}$ of plutonium metal, alloy or compound or up to $13.5 \mathrm{~kg}$ of uranium 235 metal or alloy. Additional details and restrictions are provided in 49CFR 173.396.

\section{Interior and Exterior Dimensions}

Interior $13.3 \mathrm{~cm}$ ID $\times 26.7$ in. deep inside; Drum $-39.6 \mathrm{~cm}$ diam. $\mathrm{x}$ $54 \mathrm{~cm}$ high outside with $18 \mathrm{ga}$. wall.

Description of Container

The outer container is a 57 liter DOT Spec. 17C drum. The inner container is a steel pipe with an inner diameter of $12.2 \mathrm{~cm}$ and $0.95 \mathrm{~cm}$ wall thickness (5 in. Sch 80). It has a threaded plug. The bottom end is closed by a welded steel cap. The plutonium product is contained in two sealed No. 8 steel cans which are placed inside the inner container. The inner container is lined with padding to minimize damage to the steel cans during a shipment.

Type and Thickness of Insulation

The inner container is insulated by Celotex ${ }^{\mathbb{R}}$ Industrial Board with a minimum thickness of $7.6 \mathrm{~cm}$.

Shielding

None provided, may be added within the containment vessel when required. Heat Removal Capacity

Normal 1 icensed 1 imit of 10 watts. Special permits have been issued for designs which allow for ip to 50 watts. The 10 watt 1 imit results in a containment vessel temperature 1 imit of $68^{\circ} \mathrm{C}$ for a $21^{\circ} \mathrm{C}$ ambient temperature. Special handling requirements are required when materials that generate more than 10 watts are shipped.

Authorized Modes of Transport

Vesse1, cargo or passenger-carrying aircraft, motor vehicle, rail freight, and rail express. 


\section{$\underline{\text { LLD-1 Package }}$}

A diagram of the LLD package is shown in Figure B.3. The following specifications taken from WASH-1279 summarizes the container design characteristics.

Authorized Contents

Up to $7 \mathrm{~kg}$ of $\mathrm{Pu}$ metal, or $\mathrm{Pu}-\mathrm{lJ}$ alloy containing $7 \mathrm{~kg}$ of fissile uranium or up to $4.5 \mathrm{~kg}$ of $\mathrm{Pu}$ oxide.

Interior and Exterior Dimensions

Interior $-11.4 \mathrm{~cm} \mathrm{ID} \times 26.0 \mathrm{~cm}$ high. Exterior $-42 \mathrm{~cm} \times 42 \mathrm{~cm} \times 66 \mathrm{~cm}$ high.

\section{Description of Container}

$\hat{A}$ cylindrical outer container is supported in a cage of $1.9 \mathrm{~cm}$ OD $x$ $0.16 \mathrm{~cm}$ wall seamless steel tubing. This outer container is closed by engaging the closing lugs on the bird. Seal is effected by tightening the 1 id against a gas-filled 0-ring using the hex head bolts on the 1 id assembly. The inner container is a DOT-2R container, fabricated of steel pipe with an inner diameter of $12.2 \mathrm{~cm}$ and $0.45 \mathrm{~cm}$ wall thickness ( 5 in Sch 80 ). It is closed with a threaded plug and a gas-filled 0-ring seal. The product is contained in two Ho. 8 steel cans which are placed inside the inner container. The inner container is lined with padding to minimize damage to the steel cans during transport.

Type of Shielding

None.

Heat Removal Capacity

By convection only.

Authorized Modes of Transport

Air, highway, rail, water. Fissile Class II or III by cargo only aircraft. 


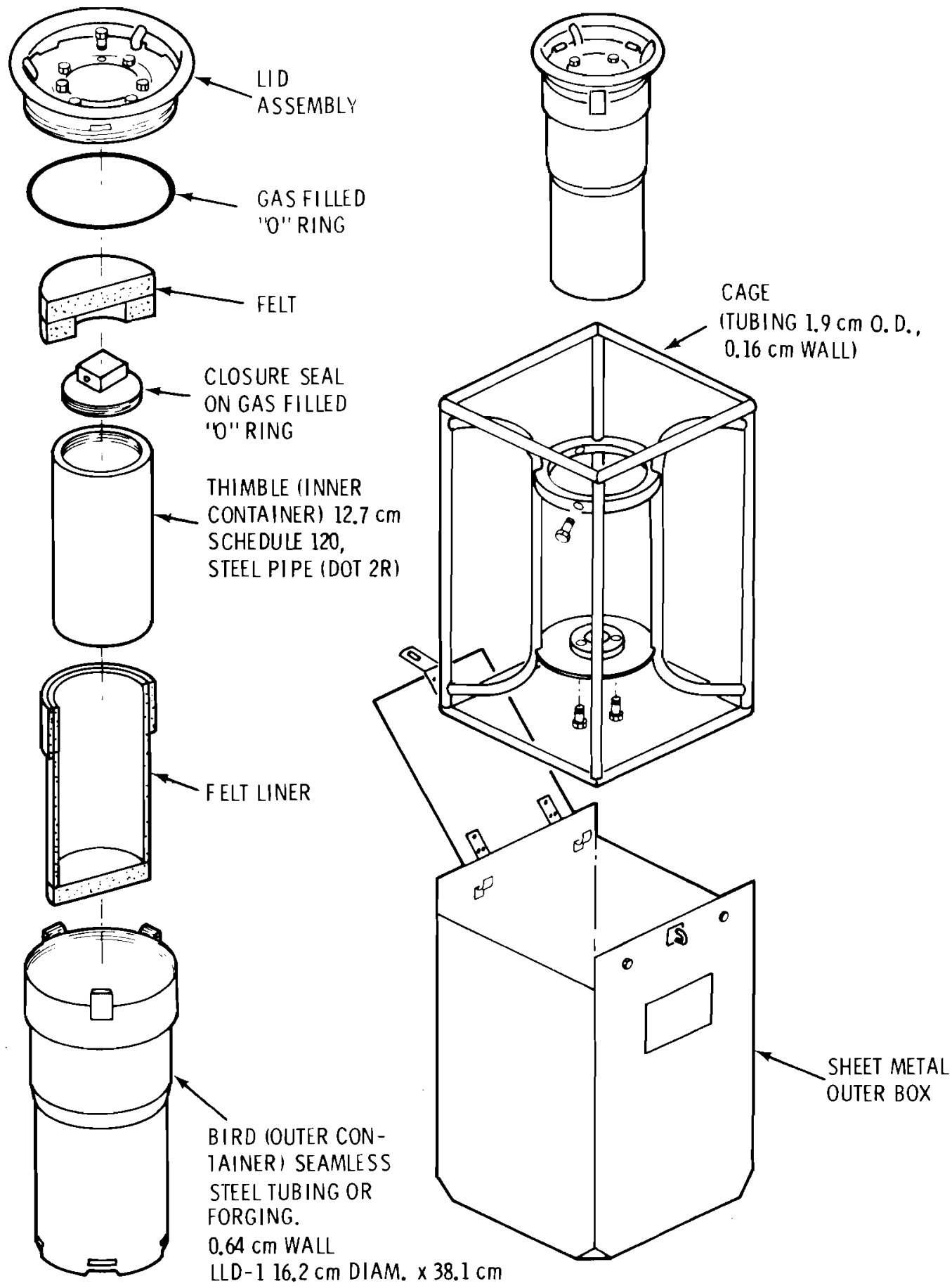

FIGURE B.3 LLD-1 Package 
. 


\section{$\underline{\text { DISTRIBUTION }}$}

No. of

Copies

OFFSITE

A. A. Churm

Chicago Patent Group

DOE Chicago Operations Office

9800 South Cass Avenue

Argonne, IL 60439

27 DOE Technical Information Center

K. A. Trickett

Division of Reactor Development and Demonstration

Department of Energy

Germantown, MD 20014

$10 \mathrm{~W}$. Brobst

Division of Environmental Control Technology

Transportation Branch

Department of Energy

Washington, DC 20545

M. Chais

Division of Environmental Control Technology

Transportation Branch

Department of Energy

Washington, DC 20545

R. F. Garrison

Division of Environmental Control Technology

Transportation Branch

Department of Energy

Washington, DC 20545

J. A. Sisler

Division of Environmental

Control Technology

Transportation Branch

Department of Energy

Washington, DC 20545
No. of

Copies
R. B. Chitwood

Waste Management Division

Department of Energy

Washington, DC 20545

R. M. Moser

DOE Chicago Operations Office 9800 South Cass Avenue

Argonne, IL 60439

W. G. O'Quinn

DOE Savannah River Operations Office

P.0. Box A

Aiken, SC 29801

iv. Stetson

DOE Savannah River Operations Office

P.0. Box A

Aiken, SC 29801

L. L. Turner

DOE Savannah River Operations Office

P.0. Box A

Aiken, SC 29801

C. Halsted

DOE Savannah River Operations Office

P.0. Box A

Aiken, SC 29801

D. Davis

DOE Albuquerque Operations Office

P.0. Box 5400

Albuquerque, NM 87115 
J. A. Lamb

DOE Oak Ridge Operations Office

P.0. Box E

Oak Ridge, TN 37830

J. J. Schreiber

DOE Oak Ridge Operations Office

P.0. Box E

Oak Ridge, TN 37830

H. Austin

DOE Oak Ridge Operations Office

P.0. Box E

Oak Ridge, TN 37830

G. R. Swindell

International Atomic Energy Agency

A-1011 Vienna, AUSTRIA

J. L. Russell

Office of Radiation Programs

AW-459, EPA

401 M St. S.W.

Washington, DC 20460

G. W. Cunningham

Assistant Administration for Nuclear Energy

Department of Energy

Washington, DC 20545

T. A. Butler

University of California

Los Alamos Scientific Laboratory

P.0. Box 1663

Los Alamos, NM 87545

D. R. Smith

University of California

Los Alamos Scientific Laboratory

P.0. Box 1663

Los Alamos, NM 87545
L. Benner

National Transportation

Safety Board

Department of Transportation

Washington, DC 20594

E. J. Wilson

Department of Transport

Dangerous Goods Branch

2 Marsham St.

London SW 1

ENGLAND

A. L. Schmieg

National Transportation

Safety Board

Department of Transportation

Washington, DC 20594

P. J. Eicker

Sandia Laboratories, Livermore Livermore, CA 94550

J. W. Langhaar

E. I. Dupont de Nemours \& Company

Savannah River Plant

Aiken, SC 29801

J. Curtis

Department of Transportation

Materials Transportation Bureau

2100 Second St. S.W.

Washington, DC 20590

A. Grella

Department of Transportation

Materials Transportation Bureau

2100 Second St. S.W.

Washington, DC 20590

Dr. H. C. Thompson

Battelle Memorial Institute

Washington Operations

20301 M St. N.W.

Washington, DC 20036 
ivo. of

Copies

W. Rowe

Environmental Protection Agency 401 M St.

Washington, DC 20460

A. J. Nertney

Aerojet Nuclear Company

550 2nd St.

Idaho Falls, ID 83401

C. Starr

Electrical Power Research Inst.

P.0. Box 10412

Palo Alto, CA 94304

C. Comar

Electrical Power Research Inst. P.0. Box 10412

Palo Alto, CA 94304

E. Zebrowski

Electrical Power Research Inst.

P.0. Box 10412

Palo Alto, CA 94304

R. Williams

Electrical Power Research Inst.

P.0. Box 10412

Palo Alto, CA 94304

Combustion Engineering, Inc.

Windsor, CT 06095

J. Desmond

Babcock \& Wilcox, Co.

P.0. Box 1260

Lynchburg, VA 24505

C. Woods

Babcock \& Wilcox Co.

P.0. Box 1260

Lynchburg, VA 24505

D. M. Krieg

Rocky Flats Plant

Atomic International Division

P.0. Box 464

Golden, CO 80401
No. of

Copies

Prof. Norman C. Rasmussen

Massachusetts Institute of Technology

Cambridge, MA 02139

L. Bonzon

Sandia Laboratories

P.0. Box 5800

Albuquerque, NM 87115

J. T. Foley

Sandia Laboratories

P.0. Box 5800

Albuquerque, NM 87115

W. F. Hartmann

Sandia Laboratories

P.0. Box 5800

Albuquerque, NM 87115

R. M. Jefferson

Sandia Laboratories

P.0. Box 5800

Albuquerque, NM 87115

T. G. Priddy

Sandia Laboratories

P.0. Box 5800

Albuquerque, NM 87115

R. Yoshimura

Sandia Laboratories

P.0. Box 5800

A1buquerque, NM 87115

N. H. Mackay

Sandia Laboratories

P.0. Box 5800

Albuquerque, NM 87115

R. F. Barker

Nuclear Regulatory Commission

Washington, DC 20555 
ivo. of

Copies

C. B. Bartlett

Nuclear Regulatory Commission

Washington, DC 20555

R. B. Minogue

ivuclear Regulatory Commission

Washington, DC 20555

C. McDonald

Nuclear Regulatory Commission

Washington, DC 20555

M. J. Steindler

Argonne National Laboratory

9700 South Cass Avenue

Argonne, IL 60439

M. J. Ryan

Argonne National Laboratory

9700 South Cass Avenue

Argonne, IL 60439

R. A. Robinson

Battelle Memorial Institute

Columbus Operations

505 King Avenue

Columbus, $\mathrm{OH} 43201$

Atomics International

8900 DeSoto Avenue

Conoga Park, CA 91304

A. L. Kaplan

General Electric Co.

Nuclear Fuel Division

P.0. Box 780

Wilmington, NC 28401

G. Lapier

Babcock \& Wilcox Co.

Apol1o, PA 15613

R. Long

Babcock \& Wilcox Co.

Apol1o, PA 15613
No. of

Copies

R. D. Seagren

Union Carbide Corporation

Oak Ridge National Laboratories

P.0. Box $X$

Oak Ridge, TN 37830

L. Shappert

Union Carbide Corporation

Oak Ridge National Laboratories

P.0. Box $X$

Oak Ridge, TN 37830

J. Duckworth

Nuclear Fuel Service, Inc.

P.0. Box 124

West Valley, NY 14171

G. L. Stukenbroeker

N. L. Industries, Inc.

Nuclear Transportation Dept.

P.0. Box 2046

Wilmington, DE 19899

H. G. Shealy

Bureau of Radiological Health

South Carolina Department of Health and Environmental Control

Columbia, SC 29405

J. S. Corbett

ChemNuclear Systems, Inc.

P.0. Box 1866

Bellevue, WA 98009

J. A. Hebert

Battelle Seattle Research Center

P.0. Box 5395

Seattle, WA 98105

P. T. Tuite

Hittman Nuclear and Development Corporation

9190 Red Branch Rd.

Columbia, MD 21045 
D. A. Edling

Mound Laboratories

P.0. Box 32

Miamisburg, $\mathrm{OH} 45342$

J. W. Doty

Mound Laboratories

P.0. Box 32

Miamisburg, $\mathrm{OH} 45342$

W. T. Cove

Mound Laboratories

P.0. Box 32

Miamisburg, OH 45342

D. Okrent

Department of Engineering and Applied Science

University of California

Los Angeles, CA 90024

M. Gordon

Atomic Industrial Forum

7101 Wiscons in Ave.

Washington, DC 20014

A. L. Babb

Department of Nuclear Engineering

Benson Hall

University of Washington

Seattle, WA 98195

W. S. Fellows

Southern Interstate Nuclear Board

One Exchange Place, Suite 1230

Atlanta, GA 30341

D. G. Maxwe 11

N. L. Industries

Nuclear Division

Foot of West Street

Wilmington, DE 19801

W. R. Teer

Transnuclear Inc.

One N. Broadway

White Plains, NY 10601
S. Hartwig

Battelle Institute, e.v.

Am Romerhof 35

600 Frankfurt Main 90

GERMANY

D. Turner

Union Carbide Corporation

Office of Waste Isolation

P.0. Box $Y$

Oak Ridge, TN 37830

S. C. Cohn

Teknekron

4701 Sangamore Rd.

Washington, DC 20016

K. R. Shultz

Atomic Energy Control Board

P.0.B. 1046

Ottawa KIP 559

CANADA

W. R. Taylor

Atomic Energy of Canada Ltd.

Chalk River Laboratories

Chalk River, Ontario KOJIJO

CANADA

Y. Sousselier

CEA/CEN

B.P. No. 6

F-92260 Fontenay-aux-Roses

FRANCE

S. Aoki

Research Laboratory for Nuclear Reactors

Tokyo Institute of Technology

Ookayama, Meguroku, Tokyo 152 JAPAN

G. D. Bell

United Kingdom Atomic Energy Authority

Safety and Reliability

Directorate

Warrington WA3 4NE

UNITED KINGDOM 
No. of

Copies

M. Tomlinson

White Shell ivuclear Research

Establishment

Pinewa, Manitoba ROE ILO

CANADA

S. A. Mayman

Fuel Recycle Waste

Management Program

Whiteshel1 Nuclear Research

Establishment

Pinewa, Manitoba ROE ILO

CANADA

Dr. R. Girardi

Euratom

21020 Centro Euratomdi

Ispra (Varesse)

ITALY

Ake Hultgren

$A B$ Atomenergi, Studsvik

Fack

S-611 ol Nyköping 1

SWEDEN

W. J. She 1 ley

Kerr-McGee Corporation

Oklahoma City, OK

R. W. Peterson

Allied General Nuclear Services

P.0. Box 847

Barnwel1, SC 29812

A. Carson

General Electric Company

175 Curtner Avenue

San Jose, CA 95125

R. A. Koynenburg

University of California

Lawrence Livermore Laboratories

P.0. Box 808

Livermore, CA 94551
No. of

Copies

W. E. Pollock

Oregon Department of Energy

Salem, OR 97301

K. Woods

Oregon Department of Energy

Salem, OR 97301

W. M. Rogers

Western Interstate Nuclear Board

1300 Carr

Denver, C0 80226

G. P. Jones

University of Southern California

University Park

Los Angeles, CA 90007

L. L. Philipson

University of Southern California

University Park

Los Angeles, CA 90007

C. V. Hodges

Holmes \& Narver

400 E. Orangethrope Ave.

Anaheim, CA 92801

E. A. Straker

Science Applications, Inc.

P.0. Box 2351

La Jolla, CA 92038

R. C. Erdman

Science Applications, Inc.

2680 Hanover St.

Palo Alto, CA 94304

G. Waymire

Exxon Nuclear Company, Inc.

P.0. Box 3990

MS $8 A-68$

Seattle, WA 98124 
No. of

Copies

OISITE

8 DOE Richland Operations office

T. A. Bauman

W. A. Burns

R. B. Goranson

A. H. Hinkson

P. E. Lamont

J. M. Peterson

H. E. Ranson

D. J. Squires

3 Rockwe 11 Hanford Company

W. G. Bevan

W. M. Harty

D. D. Woodrich

3 United Nuclear Industries, Inc.

J. A. Adams

P. A. Crosetti

T. E. Dabrowski

2 Washington Public Power Supply System

G. F. Bailey

J. B. Vetrano

2 Exxon Nuclear Company, Inc.

R. Nilsen

R. K. Robinson
No. of

Copies

Hanford Engineering Development Laboratory

A. W. DeMerschman

66 Battelle-Northwest

W. B. Andrews

W. J. Bair

C. L. Brown

N. M. Burleigh (25)

S. H. Bush

N. E. Carter

E. D. Clayton

L. C. Davenport

J. G. DeSteese

H. K. Elder

A. L. Frank lin

D. E. Friar

R. J. Hall

H. Harty

S. W. Heaberl in (10)

H. L. Henry

W. S. Kelley

M. A. Lewallen

R. A. Libby

T. I. McSweeney

J. Mishima

E. S. Murphy

D. R. Oden

R. E. Rhoads

J. W. Voss

L. D. Williams

W. K. Winegardner

Technical Information (5)

Technical Publications 
, 